\title{
An Empirical Study on the Use of Ritual Education in the Ideological and Political Education of Higher Vocational College Students in Yunnan
}

\author{
Quying Zhang* \\ A College of Marxism, Yunnan Open University, Kunming 650500, China. \\ 61330531@qq.com
}

\begin{abstract}
This paper is based on the socialist ideology of Chinese characteristics in the new era of $\mathrm{Xi}$ Jinping and the spirit of the Party's Nineteenth Congress. Based on the current situation of ideological and political ceremonial education in higher vocational colleges in ethnic minority regions, a case study was conducted using the Yunnan Vocational Technical College as an example. The analysis and research on the ideological and political education of college students in a minority of higher vocational college's places emphasis on the application and development of ceremonial education, thereby promoting the development and innovation of ideological and political education for college students.
\end{abstract}

Keywords: Ritual education, higher vocational college students, ideological and political education.

\section{Introduction}

In 2016, General Secretary Xi Jinping pointed out that:”The relationship between ideological and political work in colleges and universities, what kinds of people are to cultivate in colleges and universities, how to cultivate people, and who should be cultivated for this fundamental issue, we must adhere to the people as the central link, and ideological and political work throughout the entire process of education and teaching. To realize the entire process of educating people, to educate people in an all-round way, and to work hard to create a new situation for the development of higher education in China."This requires college ideological educators to grasp the way of ideological and political education, and constantly explore and study the new era of ideological and political education methods. As an important carrier of ideological and political education for college students, ritual plays an important role in guiding college students to set up correct values, standardize behavior standards and practice the core values of socialism, and discusses the application of ritual education in ideological and political education of higher vocational college students in minority areas, It is of great practical significance to reflect on the innovation of ideological and political education work in higher vocational college.

\section{Definition of Ceremony and Ritual Education}

In the 19th century, rituals appeared as a categorized category of human experience in the analysis of specialized words. With regard to the definition of ceremonies, different disciplines and scholars such as anthropology, ethnology, history, sociology, and so on, have defined their uselessness. From the perspective of anthropology, the development of traditional customs promotes the development of ceremonies and makes them a kind of activity and behavior which is universally accepted and recognized. The definition of ritual in modern Chinese dictionary is: Ritual is a procedure or form, such as a ceremony. Ceremony was first produced by the original religious production activities, the development of traditional customs and rituals in the lives of everyone and plays a very important role, the general need for special procedures to standardize the activities required to support the ritual. Rituals can define special moments or events that record the development of social history and culture. School ceremonies are activities organized in the school field. If an event requires a ritual, that is special in the school daily life, the school ceremony can fully reflect the school's educational function, has certain stability, and can let the student feel the good education atmosphere, represents the school 
profound cultural foundation, this is advantageous to the school and the school member's common development.

The theoretical foundation of ritual education mainly includes two aspects of the theory of situational education and the theory of empathy in aesthetics. Through the ritual education can let the student experience a kind of solemn special ritual feeling, under the edification of the ritual can let the student enrich individual's value, and to the student's psychology and the behavior has the profound lasting, imperceptible influence, thus promoting the overall development of students.

\section{The Function Analysis of Ritual Education}

\subsection{Expression Function}

The ceremony of the exhibition process embedded more and more "national symbols": first, the ritual process is the national policies of the expression and implementation, the second is the ritual process is the state and school authority of the manufacturing and maintenance. Through ritual education, students can understand the national policy and the school system orientation, students in the solemn ceremony, can fully feel the state and the authority of the school. Such as the hoisting of the flag ceremony.

\subsection{Cohesion Function}

In the process of participating in the ceremony, students will have a collective identity to their own identity and subconsciously belong to the collective, thus increasing the cohesion of the collective. For example, the entrance ceremony of the games, the collective square team, and the guidance of flags, the encouragement of slogans, the accompaniment of music, the neat pace, and every ceremonial symbol will enable every athlete to find a sense of belonging and honor, thus stimulating the collective cohesion.

\subsection{Boot Function}

The ritual process is a practice of social values. Symbols in rituals are a reflection of social values. The ceremony can vividly and profoundly affect and guide the values of university students. For example, every year the CCTV held an award ceremony that touched the top ten figures in China. During this ceremony, each person's real story is a symbol of a noble value release. The real picture, real emotions, and real words are all examples. A ritual symbol that incorporates the socialist core values. This kind of ritual affects people and guides people.

\subsection{Memory Function}

Rituals have the function of collective memory. The famous anthropologist Vangennapp in his main book, "Through the ritual," that "' personal life in any society is a sequence of transitions from one stage to another as the age increases." ' The so-called ' one phase transition to another phase ', as if time is divided into a critical state of the ' stage '. Yet this is another manifestation of the life-time system, or the sociality of the life-time period. Simply put, without a particular social ritual separating the ' one age ' from the ' other age ' in a special way, it is impossible to obtain the process attributes of social norms, which is like not being able to step into an adult society without having a rite of passage. "The ceremony is divided into three stages:" Separation "," threshold "and" combination ". The separation refers to the former identity formally detached from the relationship, the threshold refers to formally become the new identity before the transition stage, the combination of the new identity. For example, college students swear to join the ceremony. 


\section{Present Situation of Ideological and Political Education of Higher Vocational College Students in Ritual Education}

\subsection{The Current Status of Ritual Education in The Ideological and Political Education of Yunnan Vocational College Students}

Taking Yunnan a vocational and technical College Youth League for full-time students in the school group activities (2015-2016 school year) as an example, which involves ritual education activities summarized as follows:

Table 1. Involved in ritual education activities

\begin{tabular}{|c|c|c|c|}
\hline Theme & Time & Location & Participant \\
\hline $\begin{array}{c}\text { The 70th Anniversary of the Anti-Japanese } \\
\text { War }\end{array}$ & $2015 / 9 / 2$ & $\begin{array}{l}\text { Campus, } \\
\text { auditorium }\end{array}$ & $\begin{array}{l}\text { School teachers and } \\
\text { students }\end{array}$ \\
\hline Military training ceremony & 2015/10/19 & playground & Freshmen \\
\hline $\begin{array}{c}\text { Community culture festival opening } \\
\text { ceremony }\end{array}$ & 2015/11/10 & hall & Community members \\
\hline The opening ceremony of the games & 2015/11/19 & playground & $\begin{array}{l}\text { Teacher and student } \\
\text { representative }\end{array}$ \\
\hline $\begin{array}{l}\text { Qing Ma Engineering and Youth League } \\
\text { Cadre Training Start Ceremony }\end{array}$ & 2015/12/4 & Auditorium & $\begin{array}{l}\text { Student cadres, youth } \\
\text { volunteers, community } \\
\text { leaders }\end{array}$ \\
\hline $\begin{array}{c}\text { Youth Volunteers Cultural Festival } \\
\text { Launch Ceremony }\end{array}$ & $2015 / 12 / 15$ & hall & youth volunteer \\
\hline $\begin{array}{l}\text { Construction of incorrupt government } \\
\text { culture }\end{array}$ & 2015/12/31 & hall & $\begin{array}{l}\text { Teacher and student } \\
\text { representative }\end{array}$ \\
\hline Learn Lei Feng month theme activities & $2016 / 3 / 4$ & $\begin{array}{l}\text { Campus, Off- } \\
\text { campus }\end{array}$ & $\begin{array}{l}\text { Organizations of the } \\
\text { colleges }\end{array}$ \\
\hline $\begin{array}{c}\text { Commemorate the 97th Anniversary Gala } \\
\text { and Awards Ceremony of the May Fourth } \\
\text { Movement }\end{array}$ & $2016 / 5 / 6$ & hall & $\begin{array}{l}\text { Teacher and student } \\
\text { representative }\end{array}$ \\
\hline Honesty Test Advocacy Ceremony & $2016 / 6 / 6$ & $\begin{array}{l}\text { Every colleges, } \\
\text { classes }\end{array}$ & School students \\
\hline $\begin{array}{l}\text { The fourth session of the College Youth } \\
\text { League Department general ceremony }\end{array}$ & $2016 / 7 / 5$ & Classroom & Student leaders \\
\hline "Sanxiaxiang" Volunteer Activity & $\begin{array}{c}2016 / 7 / 9- \\
2016 / 7 / 14 \\
\end{array}$ & $\begin{array}{l}\text { X State y } \\
\text { Village }\end{array}$ & $\begin{array}{l}\text { League leader, student } \\
\text { leader }\end{array}$ \\
\hline
\end{tabular}

(Note: The above content from Yunnan a vocational and Technical College's Youth league Weibo and the school's Youth League teachers and student leader interview)

\subsection{Analysis of the Present Situation of Ceremonial Education in Yunnan Vocational Colleges (Take Yunnan A Vocational and Technical College as an Example)}

\subsubsection{Type and Function Analysis}

From the perspective of the ceremonial education organized by the level from the Yunnan Vocational and Technical College in the 2015-2016 school year, the number of ritual education accounts for $81.2 \%$ of the school-wide campus activities in the entire school year. A large number of campus activities are conducted in the form of ceremonies. Ritual education plays an important role in the ideological and political education of university students in the campus culture of the university. The types and functions of ceremonial education at the school are as follows:

Table 2. Types and functions of school etiquette education

\begin{tabular}{|c|c|}
\hline Type of ritual & Function \\
\hline Symbol class & Symbolizes the start or end of a theme activity \\
\hline Celebration class & Celebrating a major holiday \\
\hline Incentives class & Affirmation and motivation for outstanding students in all fields \\
\hline
\end{tabular}




\subsubsection{The Role of Play and Problems}

(I) Ritual education explains the spirit of the times. Judging from the ritual education organized by the school, the theme of the times is closely linked with the spirit of the times. Students can learn about the country's history and culture and major policies in various ritual education, cultivate students' patriotic plots, guide students in their sensibility and patriotism, and inspire students to give full play to their special talents and improve their overall quality.

(II) Ritual education practices the core values of socialism. Judging from the school's ritual education themes, ritual education practices its core values of socialism in its unique form, entertains them, and allows college students to profoundly understand the connotations of socialist core values in practice.

(III) Ritual education has shaped a good school style. For example, in the initiative of the integrity test and in various award ceremonies, solemn scenes, serious procedures, inspiring accompaniment, reading of the leadership, glory of the awards on stage, etc., the release of each symbol inspired the college students to work hard. This type of ritual education not only motivates the parties, but also educates onlookers subtly, thus creating a good school style.

\subsubsection{Existing Problems}

(1) The function of ritual education is not fully recognized, and ritual education flows into "form." The ritual education only stays in the form of the ritual. It means more or less the beginning or the end of the main activity. It does not give full play to the ideological and political education function of the ritual.

(2) The degree of participation in ritual education is not high. Judging from the degree of student participation, for the existing ritual education, students' participation is not high, and ritual education is more limited to small-scale student cadres, associations, young volunteers, and a certain class of lovers.

(3) Failing to give full play to the characteristics of ethnic culture. The ceremonial education is more of a work task that is issued at the next level of practice. It is a ceremonial activity that is performed in order to complete the relevant work and do a good job of advertising and reporting. We do not give full play to China's traditional excellent culture, but did not reflect the cultural characteristics of higher vocational colleges in minority areas.

(4) Cannot carry out ritual education according to school characteristics. Judging from the content of the ritual education organized by the school, it does not combine with the characteristics of higher vocational education, and has less content in terms of production, education, research, and employment and entrepreneurship.

\section{Practice and Development of Ritual Education in Ideological and Political Education for Students in Higher Vocational Colleges in Yunnan}

\subsection{The Ritual Education Must be Combined with Marxist Scientific Theory}

General Secretary Xi Jinping pointed out: "Our colleges and universities are colleges and universities under the leadership of the party and socialism colleges with Chinese characteristics. To handle our colleges and universities well, we must adhere to the guidance of Marxism and fully implement the party's education policy. We must persevere in spreading Marxist science. Theory, do a good job of education in Marxist theory, and lay a scientific ideological foundation for students to grow and grow." The learning path of Marxist scientific theory should be diversified and threedimensional, ritual education is a very good way of practicing Marxist scientific theory. The ritual process incorporates Marxist scientific theories, uses the expressive function, guiding function, and cohesive function of rituals to allow college students to understand and grasp Marxist scientific theories through extracurricular campus cultural approaches. 


\subsection{Ritual Education Must Conform to The Socialist Core Values}

General Secretary Xi Jinping believes that "we must unremittingly cultivate and promote the core values of socialism and guide teachers and students to be strong believers, active communicators, and model practitioners of socialist core values." The practice of ritual education must be integrated with the core of socialism. The connotation of values, grasp the moral quality and psychology of college students, attach importance to the practicality of ceremonial education, actively disseminate and practice the core values of socialism, combine theory and practice, promote the internalization of socialist core values, and externalize people.

\subsection{Ritual Education Should Inherit the Excellent Traditional Culture of the Chinese Nation}

"The Chinese ethnic group formed a unique traditional culture after 5,000 years of history. The essence of Chinese traditional culture reflects the cultural history, spiritual connotation and life value of the Chinese nation is China's most precious cultural heritage and spiritual wealth. General Secretary Xi Jinping visited Shandong. At the same time, he emphasized that "to achieve the great rejuvenation of the Chinese nation, we must develop Chinese culture", and that the new generation of college students as the motherland must inherit and develop China's outstanding traditional culture, which is to promote the realization of the Chinese dream of the great rejuvenation of the Chinese dream. The significance of this." The combination of ritual education and the inheritance of the Chinese traditional culture allows university students to understand and become familiar with the extensive and profound traditional Chinese culture through new ways and to develop and inherit the essence of traditional Chinese culture.

\subsection{Ritual Education Should Embody the Distinctive Culture of Ethnic Minorities}

There are 26 nationalities in Yunnan, of which there are 25 ethnic minorities and rich ethnic cultures. The higher vocational colleges in Yunnan region are mostly students from Yunnan, who are mostly born in the minority areas, and the local minority culture. Based on this, Yunnan higher vocational colleges can give full play to the students ' knowledge of local minority culture, organize related campus culture, guide students to establish "cultural consciousness", cultivate students ' sense of pride in local minority culture, and thus help to inherit local minority culture.

\subsection{Ritual Education Should fully Embody the Idea of Running a Higher Vocational College}

"In 2016, when Prime Minister Li Keqiang stressed the importance of excellence in the meeting, we must pass on the spirit of the craftsman." The task of higher vocational colleges is to train professional and technical talents of excellence. In order to realize the cultivation of craftsman spirit in higher vocational colleges, we must adhere to the combination of production and education, promote school-enterprise cooperation, promote the harmonious development and exchange between teachers and students, provide a good environment for teachers ' teaching, and enable students to acquire knowledge better through practice, so that students can cultivate a reverence for occupation and perseverance in the process of learning. So as to form a dedicated, fine industry and a dedicated sense of mission and responsibility, to cultivate more talent for excellence. "Ritual education should be combined with the idea of cultivating skilled technicians with craftsman spirit in higher vocational colleges, to hold a number of ritual activities which embody the integration of production and education, school-enterprise cooperation," devotion, service and precision ", and inspire the students ' motivation and interest in vocational colleges, and improve the social mission of higher vocational college students.

\subsection{Ritual Education Should Embody Innovative Entrepreneurship}

"The training of professionals is inseparable from the support of education, and education reform should focus on innovation and entrepreneurship. Higher vocational colleges should have a strong sense of social responsibility and strive to cultivate new types of professionals to lay the foundation for China's innovation-driven development. In 2015, it issued the "Implementation Opinions on Deepening the Reform of Innovation and Entrepreneurship Education in Colleges and Universities" 
and put forward a series of requirements and recommendations for effective education reform. In 2016, the Ministry of Education was deeply aware of the importance of effective innovation and entrepreneurship education reform and effectively cultivated it. Innovative and entrepreneurial talents are the focus of education reform, and clearly point out that if higher education wants to achieve the bottleneck of reform breakthroughs, innovation and entrepreneurship education must be regarded as the focus, so as to promote the overall development of higher education." The theme of innovation and entrepreneurship is in the form of ritual activities. Demonstrate and create a campus atmosphere for innovation and entrepreneurship, guide students to correctly understand innovation and entrepreneurship, motivate students to actively participate in various innovation and entrepreneurship competitions, and improve students' innovation and entrepreneurship. For example, during the exhibition held in the Creative Entrepreneurship Experimental Area, students do their own innovative products. The school improves the exhibition and sales of the experimental venues, inspires the students' spirit of innovation, and enhances their entrepreneurial interest and ability.

\section{References}

[1]. People's network. Ideological and political work runs through the whole process of education and teaching [N/OL]. (2016-12-08). [2017-04-22].http://cpc.people.com.cn/n1/2016/1208/c6409428935836. html.

[2]. Peng Sharing, "Theory and practice of anthropological ritual”, Nationalities Press, Beijing, 2006.

[3]. Cao Xianyao act, "Modern Chinese dictionary", Commercial Press, Beijing, 2005.

[4]. Wu Jading," Ritual Education: effective carrier of school moral education “,education exploration'2014 (12)

[5]. Wang Rung," On the application of ritual education in the political education of University thinkers", school party building and ideological education, 2014 (9).

[6]. Peng Sharing," A review of anthropological ritual studies", National Studies , 2002(3)

[7]. Huang Singing, Chen Waging. "The essence of Chinese traditional culture is integrated into the way of Ideological and political education for contemporary college students". Journal of Higher Education2017 (6).

[8]. 13th Five-Year" the path of the development of Higher Vocational Education - the joint meeting of the national higher vocational college principals will review Cheng Yu in 2016; - "Vocational and technical education" - 2016-11- 25. 